Supporting Information for:

\title{
Shape Selective Sensing of Lipids in Aqueous Solution by a Designed Fluorescent Molecular Tube
}

\author{
Berkeley J. Shorthill, Christopher T. Avetta, and Timothy E. Glass* \\ Department of Chemistry, University of Missouri - Columbia, Columbia, MO 65211
}

\section{Titration methods}

For fluorescence titrations, a $10^{-5} \mathrm{M}$ or $10^{-6} \mathrm{M}$ solution of the sensor was prepared in buffer solution (20 mM HEPES, adjusted to $\mathrm{pH}=8.4$ ). This solution was placed in a cuvette $(1 \mathrm{ml})$ at ambient temperature. The sample was then titrated with a solution of the lipid (0.01-0.001 $\mathrm{M}$ in $20 \mathrm{mM}$ HEPES, adjusted to $\mathrm{pH}=8.4$ with $10^{-5} \mathrm{M}$ (or $10^{-6} \mathrm{M}$ ) sensor to prevent dilution). The change in fluorescence was fit to a typical one site binding isotherm ${ }^{1}$ using Graphpad Prism $^{\mathrm{TM}}$ to derive an equilibrium constant. The maximum change in fluorescence $\left(\mathrm{I}_{\mathrm{sat}}\right)$ was calculated from the theoretical fit at complete saturation. A 1:1 binding isotherm was assumed for all titrations. Because of the low binding constants of most guests and the limit of solubility of the sensors, Job experiments could only be performed for the best binding guest, dodecanoic acid (Figure S1). In this case, 1:1 binding stoichiometry was confirmed. Modeling indicated that guests which were 12 carbons or shorter could not thread more than one sensor, therefore the assumption that shorter guests also bind with 1:1 stoichiometry is reasonable.

\footnotetext{
${ }^{1}$ Connors, K. A. Binding Constants; John Wiley; New York, 1987.
} 


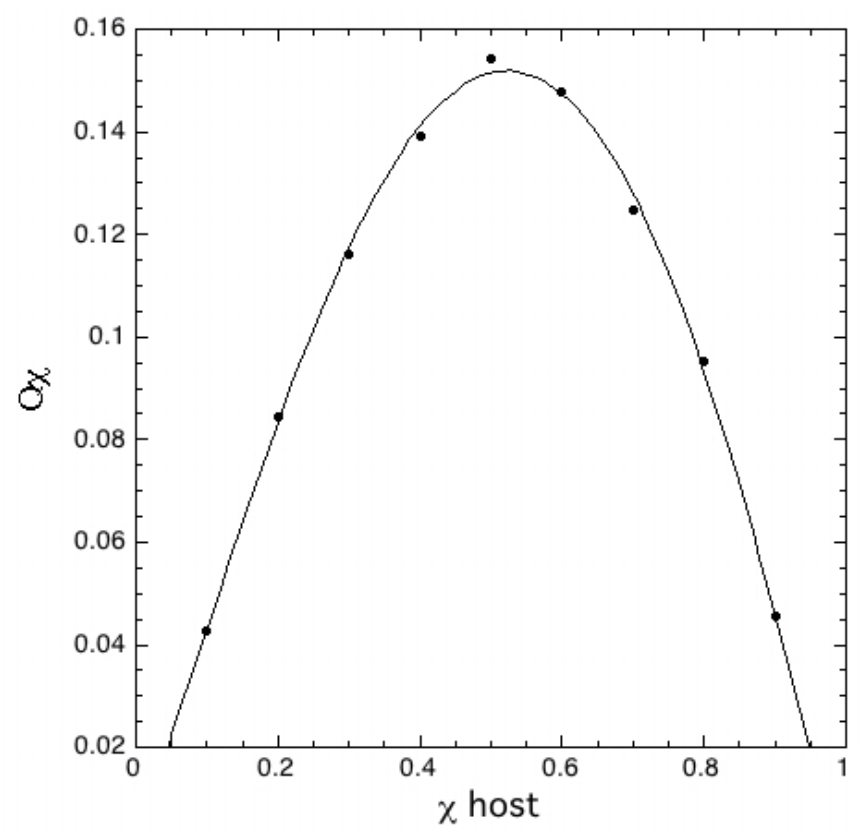

Figure S1. Job plot for sensor 1a and dodecanoic acid in buffer as described in the text. The total concentration of $1 \mathrm{a}$ and guest was maintained at $4 \times 10^{-4} \mathrm{M}$. Fluorescent response ( $\mathrm{Q}$ is defined as the fraction of fluorescence quenched) is plotted versus the mole fraction of host $(\chi)$. A maximum at 0.5 mol fraction host indicates a 1:1 binding mode.

For UV/vis and fluorescence titrations, the final concentration of guest in each experiment was at least an order of magnitude below the critical micelle concentration $(\mathrm{CMC})^{2}$ for all guests and more than two orders of magnitude below for most guests. Thus, it was assumed that the guests were discrete dissociated species in these experiments. The sensors both displayed Beer's law behavior over the concentration range in which they were used $(1-10 \mu \mathrm{M})$. Furthermore, titrations run with sensor concentrations of 1 and $10 \mu \mathrm{M}$ gave the same results (both binding constants and $\mathrm{I}_{\text {sat }}$ ).

\footnotetext{
${ }^{2}$ Critical Micelle Concentrations of Aqueous Surfactant Systems, Mukerjee, P., Mysels, K.J.; National Standard Reference Data System: Washington, D.C. 1970.
} 
These results suggest that the sensor is not aggregated under the titration conditions. For the NMR work, guest concentrations approached (but did not exceed) their CMC values, so no quantitative data was taken from these experiments.

\section{Synthetic Procedures}

Compound 2: $\mathrm{NaH}(1.37 \mathrm{~g}, 60 \%$ in mineral oil, $34 \mathrm{mmol})$ was added to a solution of 2,6-dihydroxynaphthalene $(5.0 \mathrm{~g}, 31 \mathrm{mmol})$ in DMF $(155 \mathrm{~mL})$. After stirring for 1 hour, methyl bromoacetate $(3.25 \mathrm{~mL}, 34 \mathrm{mmol})$ was added via syringe, and the resulting mixture was stirred for $16 \mathrm{~h}$. DMF was removed in vacuo, and the remaining residue was partitioned between EtOAc and 10\% $\mathrm{HCl}$. After collecting the organic layer, the aqueous phase was extracted with additional EtOAc $(2$ X $200 \mathrm{~mL})$. The combined organic layers were dried over $\mathrm{Na}_{2} \mathrm{SO}_{4}$ and filtered. After removal of the solvents in vacuo, purification by chromatography $\left(5 \% \mathrm{Et}_{2} \mathrm{O} / \mathrm{DCM}\right)$ gave the mono-alkylated product $(2.39 \mathrm{~g}, 33 \%)$ as a solid. ${ }^{1} \mathrm{H}$ NMR (300 MHz, MeOD): $\delta 7.60$ (d, 1H, $\left.J=9.3\right) 7.57$ (d, 1H, $\left.J=9.4\right) 7.07$ (m, 4H), 4.77 (s, 2H), $3.80(\mathrm{~s}, 3 \mathrm{H}) .{ }^{13} \mathrm{C}$ NMR (75 MHz, MeOD) $\delta$ 171.6,155.3, 155.1, 132.2, 130.4, 129.4, 128.9, 119.8, 119.7, 110.1, 108.5, 66.2, 52.6. IR (neat, $\mathrm{cm}^{-1}$ ) 3554, 1741, 1604. HRMS for $\mathrm{M}+\mathrm{H}^{+}$calcd for $\mathrm{C}_{13} \mathrm{H}_{13} \mathrm{O}_{4} 233.0808$, found 233.0810 .

Malonaldehyde bis(dimethylacetal) $(1.1 \mathrm{~mL}, 6.7 \mathrm{mmol})$ was added dropwise over 5 min to a solution of the above mono-alkylated product $(2.39 \mathrm{~g}, 10 \mathrm{mmol})$ and TFA (18 $\mathrm{mL})$ in DCM $(120 \mathrm{~mL})$. After the addition was complete, the mixture was stirred $4 \mathrm{~h}$ under a drying tube $\left(\mathrm{CaCl}_{2}\right)$. The reaction was poured over crushed ice, followed by the slow addition of $33 \mathrm{~mL} 6 \mathrm{M} \mathrm{NaOH}$. The $\mathrm{pH}$ of the resulting mixture was brought to ca. 8 by addition of sat. $\mathrm{NaHCO}_{3}$. Following extraction with DCM (3 X $\left.125 \mathrm{~mL}\right)$, the 
combined organic layers were washed with sat. $\mathrm{NaHCO}_{3}(1 \mathrm{X} 500 \mathrm{~mL})$, dried over $\mathrm{Na}_{2} \mathrm{SO}_{4}$, and filtered. Solvents were removed in vacuo and the residue was purified by silica chromatography $\left(0.5-1 \% \mathrm{Et}_{2} \mathrm{O} / \mathrm{DCM}\right)$ to give compound $2(1.96 \mathrm{~g}, 76 \%)$ as a white solid (mp 176-178 $\left.{ }^{\circ} \mathrm{C}\right) .{ }^{1} \mathrm{H}$ NMR (300 MHz, $\mathrm{d}_{2}$-DCM): $\delta 8.49$ (d, 2H, $J=9.3$ ), 7.48 (d, $2 \mathrm{H}, J=8.9), 7.29(\mathrm{dd}, 2 \mathrm{H}, J=9.3,2.7), 7.11(\mathrm{~d}, 2 \mathrm{H}, J=8.9), 7.00(\mathrm{~d}, 2 \mathrm{H}, J=2.7), 6.24$ (s, 1H), $5.28(\mathrm{~s}, 1 \mathrm{H}), 4.69(\mathrm{~s}, 4 \mathrm{H}), 3.77(\mathrm{~s}, 6 \mathrm{H}), 2.42(\mathrm{t}, 2 \mathrm{H}, J=2.6) .{ }^{13} \mathrm{C} \mathrm{NMR}(90 \mathrm{MHz}$, $\mathrm{d}_{2}$-DCM) $\delta 169.7,154.7,149.6,131.1,127.8,127.4,125.1,119.6,119.5,118.9,109.2$ 92.1, 66.0, 52.6, 27.3, 23.5. IR (neat, $\mathrm{cm}^{-1} 2954,1759,1604$ ). HRMS for $\mathrm{M}+\mathrm{H}^{+}$calcd for $\mathrm{C}_{29} \mathrm{H}_{25} \mathrm{O}_{8} 501.1549$, found 501.1546 .

Dialdehyde 3: A solution of compound $2(1.03 \mathrm{~g}, 2.1 \mathrm{mmol})$ in DCM $(21 \mathrm{~mL})$ was cooled to $0{ }^{\circ} \mathrm{C}$. Following addition of $\alpha, \alpha$-dichloromethyl methyl ether $(0.75 \mathrm{~mL}, 8.2$ $\mathrm{mmol}), \mathrm{TiCl}_{4}(1.0 \mathrm{M}$ in DCM $)(8.2 \mathrm{~mL}, 8.2 \mathrm{mmol})$ was added via syringe. After $1 \mathrm{~h}$ at 0 ${ }^{\circ} \mathrm{C}$, the resulting mixture was warmed to $\mathrm{rt}$ for $2.5 \mathrm{~h}$. Ice was added to the reaction mixture, which was then poured into a sat. solution of $\mathrm{NaHCO}_{3}$. Following extraction with DCM ( 3 X $75 \mathrm{~mL})$, the combined organic layers were washed consecutively with sat. $\mathrm{NaHCO}_{3}(200 \mathrm{~mL})$ and $\mathrm{H}_{2} \mathrm{O}(200 \mathrm{~mL})$, dried over $\mathrm{Na}_{2} \mathrm{SO}_{4}$, and filtered. The residue obtained after removal of solvents in vacuo was purified by chromatography (3-15\% $\left.\mathrm{Et}_{2} \mathrm{O} / \mathrm{DCM}\right)$ to give the dialdehyde $3(0.88 \mathrm{~g}, 77 \%)$ as a yellow solid. ${ }^{1} \mathrm{H}$ NMR (300 MHz, d2 2 -DCM): $\delta 10.9$ (s, 2H), $9.03(\mathrm{~d}, 2 \mathrm{H}, J=9.4), 8.72(\mathrm{~d}, 2 \mathrm{H}, J=9.5), 7.28$ (dd, 4H, $J=9.5,1.7), 6.28(\mathrm{~s}, 1 \mathrm{H}), 5.29(\mathrm{~s}, 1 \mathrm{H}), 4.88(\mathrm{~s}, 4 \mathrm{H}), 3.80(\mathrm{~s}, 6 \mathrm{H}), 2.47(\mathrm{t}, J=2.6) .{ }^{13} \mathrm{C}$ NMR (75 MHz, d 2 -DCM) $\delta 192.3,169.2,160.7,150.1,131.3,128.1,127.4,125.9,122.5$, 119.2, 119.0, 114.4, 92.0, 67.0, 52.9, 27.2, 23.4. IR (neat, $\mathrm{cm}^{-1} 2955,1759,1672$ ) . HRMS for $\mathrm{M}+\mathrm{H}^{+}$calcd for $\mathrm{C}_{31} \mathrm{H}_{25} \mathrm{O}_{10} 557.1442$ found 557.1460. 
Boc-protected diamine 5: $t$-Butyl carbamate $(0.206 \mathrm{~g}, 1.8 \mathrm{mmol})$ was added to a solution of dialdehyde (3) $(0.163 \mathrm{~g}, 0.29 \mathrm{mmol})$ in $\mathrm{MeCN}(4 \mathrm{~mL})$ and $\mathrm{DCM}(1.5 \mathrm{~mL})$. To this mixture was added triethylsilane $(0.28 \mathrm{~mL}, 1.8 \mathrm{mmol})$ and TFA $(0.09 \mathrm{~mL}, 1.2$ mmol). The resulting mixture was stirred for $16 \mathrm{~h}$ (adding DCM to maintain solubility, if necessary). Following addition of saturated aqueous $\mathrm{NaHCO}_{3}$, the aqueous layer was extracted with DCM ( 3 X $25 \mathrm{~mL})$. The combined organic were dried over $\mathrm{Na}_{2} \mathrm{SO}_{4}$ and filtered. After removal of solvents, the residue was purified by chromatography (excess TES eluted with DCM, 5-10\% $\mathrm{Et}_{2} \mathrm{O} / \mathrm{DCM}$ to recover product). The $\mathrm{BOC}$ protected diamine $5(0.147 \mathrm{~g}, 66 \%)$ was obtained as an off-white solid (mp $103^{\circ} \mathrm{C}$ dec.). ${ }^{1} \mathrm{H}$ NMR (300 MHz, d $\mathrm{d}_{2}$-DCM): $\delta 8.50$ (d, 2H, $\left.J=9.4\right), 8.03$ (d, $\left.2 \mathrm{H}, J=9.3\right), 7.24$ (d, $2 \mathrm{H}, J=10$ ), $7.20(\mathrm{~d}, 2 \mathrm{H}, J=9.6), 6.26(\mathrm{~s}, 1 \mathrm{H}), 5.30(\mathrm{~s}, 3 \mathrm{H}), 4.82(\mathrm{~s}, 2 \mathrm{H}), 4.81(\mathrm{~s}, 2 \mathrm{H}), 4.73(\mathrm{dd}, J=$ 5.4, 2.6), 3.78 (s, 6H), 2.43 (s, 2H), 1.37 (s, 18H). ${ }^{13} \mathrm{C} \mathrm{NMR}\left(75 \mathrm{MHz}, \mathrm{d}_{2}-\mathrm{DCM}\right) \delta 170.3$, $156.2,152.7,149.6,129.5,127.8,124.8,124.6,123.2,120.1,119.4,114.6,92.1,79.3$, 67.1, 52.8, 35.4, 28.6, 27.4, 23.5. IR (neat, $\mathrm{cm}^{-1} 3414,2976,1755,1703,1600$ ) . HRMS for $\mathrm{M}+\mathrm{H}^{+}$calcd for $\mathrm{C}_{41} \mathrm{H}_{47} \mathrm{~N}_{2} \mathrm{O}_{12} 759.3123$ found 759.3159 .

Diacid 4: A solution of dialdehyde $3(0.200 \mathrm{~g}, 0.36 \mathrm{mmol})$ in acetone $(7 \mathrm{~mL})$, THF (7 $\mathrm{mL})$, and $\mathrm{H}_{2} \mathrm{O}(14 \mathrm{~mL})$ was cooled to $0{ }^{\circ} \mathrm{C}$. Sulfamic acid $(0.209 \mathrm{~g}, 2.2 \mathrm{mmol})$ and sodium chlorite $(0.203 \mathrm{~g}, 1.8 \mathrm{mmol}, 80 \%)$ were added. The mixture was slowly warmed to $\mathrm{rt}$ and kept there for $14 \mathrm{~h}$. After addition of sat. aqueous ammonium chloride, the product was extracted with EtOAc $(2 \times 25 \mathrm{~mL})$. The combined organic layers were dried over $\mathrm{Na}_{2} \mathrm{SO}_{4}$ and filtered. After removal of the solvents in vacuo, the residue was purified by eluting through a short column of silica with 5/1/94 MeOH/HOAc/DCM. The diacid (4) (0.200 g, 95\%) was obtained as a pale yellow solid (mp $170^{\circ} \mathrm{C}$ dec.). ${ }^{1} \mathrm{H}$ 
NMR (300 MHz, MeOD): $\delta 8.68(\mathrm{~d}, 2 \mathrm{H}, J=9.5), 7.61(\mathrm{~d}, 2 \mathrm{H}, J=9.2), 7.35(\mathrm{~d}, 2 \mathrm{H}, J=$ 9.4), $7.17(\mathrm{~d}, 2 \mathrm{H}, J=9.1), 6.26(\mathrm{~s}, 1 \mathrm{H}), 5.43(\mathrm{~s}, 1 \mathrm{H}), 4.84(\mathrm{~s}, 4 \mathrm{H}), 3.78(\mathrm{~s}, 6 \mathrm{H}), 2.40(\mathrm{~s}$, 2H). ${ }^{13} \mathrm{C}$ NMR (75 MHz, 2:1 MeOD/DCM) $\delta 170.9,170.7,151.2,150.2,127.8,127.5$, $126.7,125.2,121.9,120.9,119.8,115.5,92.5,67.6,52.6,27.3,23.6$. IR (neat, $\mathrm{cm}^{-1} 4500$ 1800, 1710). HRMS for $\mathrm{M}+\mathrm{Li}^{+}$calcd for $\mathrm{C}_{13} \mathrm{H}_{24} \mathrm{O}_{12} \mathrm{Li} 595.1428$ found 595.1394.

Sensor 1: TFA (1mL) was added to a solution of Boc-protected diamine 5 (0.075 g, $0.099 \mathrm{mmol})$ in DCM $(2 \mathrm{~mL})$. After stirring for $16 \mathrm{~h}$, the solvents were removed in vacuo $\left(<35{ }^{\circ} \mathrm{C}\right) . \mathrm{CHCl}_{3}(5 \mathrm{~mL})$ was added and solvents were again removed in vacuo $\left(<35^{\circ} \mathrm{C}\right)$. The remaining bis(TFA) salt of the diamine was dried under high vacuum for $24 \mathrm{~h}$ to remove any residual TFA. The dry diamine was taken up in DMF (10 mL) (flask A). In a separate flask (B), diacid (4) (0.058 g, $0.099 \mathrm{mmol})$ was combined with PyBOP (0.206 g, $0.40 \mathrm{mmol})$ and Hunig's base $(0.17 \mathrm{~mL}, 0.99 \mathrm{mmol})$ in DMF $(10 \mathrm{~mL})$. In a third flask (C) was placed DMF (20 mL). Using a double syringe pump, the contents of flask A and flask B (separate syringes) were added dropwise to flask C over a period of $1.5 \mathrm{~h}$. The resulting mixture was stirred for $16 \mathrm{~h}$. Solvents were removed in vacuo, and the resulting residue was taken up in DCM $(50 \mathrm{~mL})$. The organic layer was washed with $10 \%$ aqueous $\mathrm{HCl}(50 \mathrm{~mL})$ followed by sat. aqueous $\mathrm{NaHCO}_{3}(50 \mathrm{~mL})$ and dried over $\mathrm{Na}_{2} \mathrm{SO}_{4}$. Following removal of the solvent in vacuo, the residue was purified by column chromatography (EtOAc) to give the tetramethyl ester as a mixture of diastereomers $(0.038 \mathrm{~g}, 35 \%)$.

Sodium hydroxide $(0.5 \mathrm{~mL}, 6 \mathrm{M})$ was added to a solution of the above tetramethyl ester $(0.030 \mathrm{~g}, 0.027 \mathrm{mmol})$ in $\mathrm{MeOH}(1 \mathrm{~mL})$ and THF $(1 \mathrm{~mL})$. After stirring overnight, the reaction was quenched with $10 \% \mathrm{HCl}(5 \mathrm{~mL})$, extracted with a mixture of 
$\mathrm{MeOH} / \mathrm{DCM}(5 \times 10 \mathrm{~mL})$, and dried over $\mathrm{Na}_{2} \mathrm{SO}_{4}$. Solvents were removed in vacuo to give the final sensor $1(0.027 \mathrm{~g}, 95 \%)$ as a crude mixture of diastereomers. The two isomers were separated by reverse-phase HPLC (ramping from 15-25\% acetonitrile in phosphate buffer ( $\mathrm{pH}$ 7.5) over $30 \mathrm{~min}$.). After multiple injections, like fractions were combined and extracted with $\mathrm{MeOH} / \mathrm{DCM}$. After drying with $\mathrm{Na}_{2} \mathrm{SO}_{4}$, solvents were removed in vacuo to give the separate isomers. Tritration with $\mathrm{CCl}_{4}$ was often required to remove residual aliphatic contaminants. Assignment of syn versus anti was made by 2D NMR (COSY/NOESY).

Syn isomer: ${ }^{1} \mathrm{H}$ NMR $\left(500 \mathrm{MHz}, \mathrm{d}_{6}\right.$-DMSO) : $\delta 8.56(\mathrm{~d}, 2 \mathrm{H}, J=9.6), 8.52(\mathrm{~d}, 2 \mathrm{H}, J=$ 9.6), $7.72(\mathrm{~d}, 2 \mathrm{H}, J=9.3), 7.51(\mathrm{~d}, 2 \mathrm{H}, J=9.3), 7.19$ (d, $2 \mathrm{H}, J=9.5), 7.15(\mathrm{~d}, 2 \mathrm{H}, J=$ 9.2), $7.11(\mathrm{~d}, 2 \mathrm{H}, J=9.5), 7.10(\mathrm{~d}, 2 \mathrm{H}, J=9.1), 6.32(\mathrm{~s}, 1 \mathrm{H}), 6.27(\mathrm{~s}, 1 \mathrm{H}), 5.60(\mathrm{~s}, 2 \mathrm{H})$, 4.98 (dd, $2 \mathrm{H}, J=13.1,8.4), 4.67$ (m, 8H), 4.53 (d, $2 \mathrm{H}, J=13.36$ ), 2.54 (bs, $2 \mathrm{H}), 2.43$ (bs, $2 \mathrm{H}) .{ }^{13} \mathrm{C}$ NMR (125 MHz, $\mathrm{d}_{6}$-DMSO): $\delta$ 171.1, 170.6, 165.3, 165.1, 152.3, 150.3, 148.8 , $148.7,148.4,128.0,126.9,126.7,126.1,126.0,125.2,124.2,123.3,121.9,120.8,120.6$, $120.0,119.6,119.1,118.9,115.2,114.5,90.6,90.4,66.9,66.1,33.1,25.2,25.0,22.4$, 21.3.IR (neat, $\mathrm{cm}^{-1}$ ) 3401, 2924, 1724, 1633. HRMS for $\left(\mathrm{M}-\mathrm{H}^{+}\right)^{-}$calcd for $\mathrm{C}_{58} \mathrm{H}_{42} \mathrm{~N}_{2} \mathrm{O}_{18}$ 1053.2354, found 1053.0.

Anti isomer: ${ }^{1} \mathrm{H}$ NMR (500 MHz, $\mathrm{d}_{6}$-DMSO): $\delta 8.49$ (d, $\left.2 \mathrm{H}, J=9.2\right), 8.48(\mathrm{~d}, 2 \mathrm{H}, J=$ 9.3), 7.87 (bs, 2H), $7.54(\mathrm{~d}, 2 \mathrm{H}, \mathrm{J}=9.3), 7.38(\mathrm{~d}, 2 \mathrm{H}, J=9.1), 7.07(\mathrm{~d}, 2 \mathrm{H}, J=9.4), 7.01$ (d, 2H, $J=9.4), 6.98$ (d, 2H, $J=9.2), 6.92(\mathrm{~d}, 2 \mathrm{H}, J=9.1), 6.28(\mathrm{~s}, 1 \mathrm{H}), 6.28(\mathrm{~s}, 1 \mathrm{H})$, $5.55(\mathrm{~s}, 1 \mathrm{H}), 5.53(\mathrm{~s}, 1 \mathrm{H}), 5.21(\mathrm{dd}, 2 \mathrm{H}, J=13.9,6), 4.58(\mathrm{~m}, 6 \mathrm{H}), 4.45(\mathrm{~d}, 2 \mathrm{H}, J=16.2)$, $4.36(\mathrm{~d}, 2 \mathrm{H}, J=11.1), 2.53$ (s, 2H), 2.49 (s, 2H, obscured by $\mathrm{d}_{6}$-DMSO peak). ${ }^{13} \mathrm{C}$ NMR (125 MHz, $\mathrm{d}_{6}$-DMSO): $\delta 170.8,170.3,165.5,151.5,149.9,148.7,148.3,128.7,126.7$, 
126.6, 126.2, 125.6, 124.9, 124.3, 123.1, 122.9, 119.5, 119.3, 118.9, 114.7, 114.0, 90.7, 66.2, 65.9, 33.371, 29.0, 21.3. IR (neat, $\mathrm{cm}^{-1}$ ) 3376, 3202, 2922, 1723. HRMS for (M$\left.\mathrm{H}^{+}\right)^{-}$calcd for $\mathrm{C}_{58} \mathrm{H}_{42} \mathrm{~N}_{2} \mathrm{O}_{18}$. 


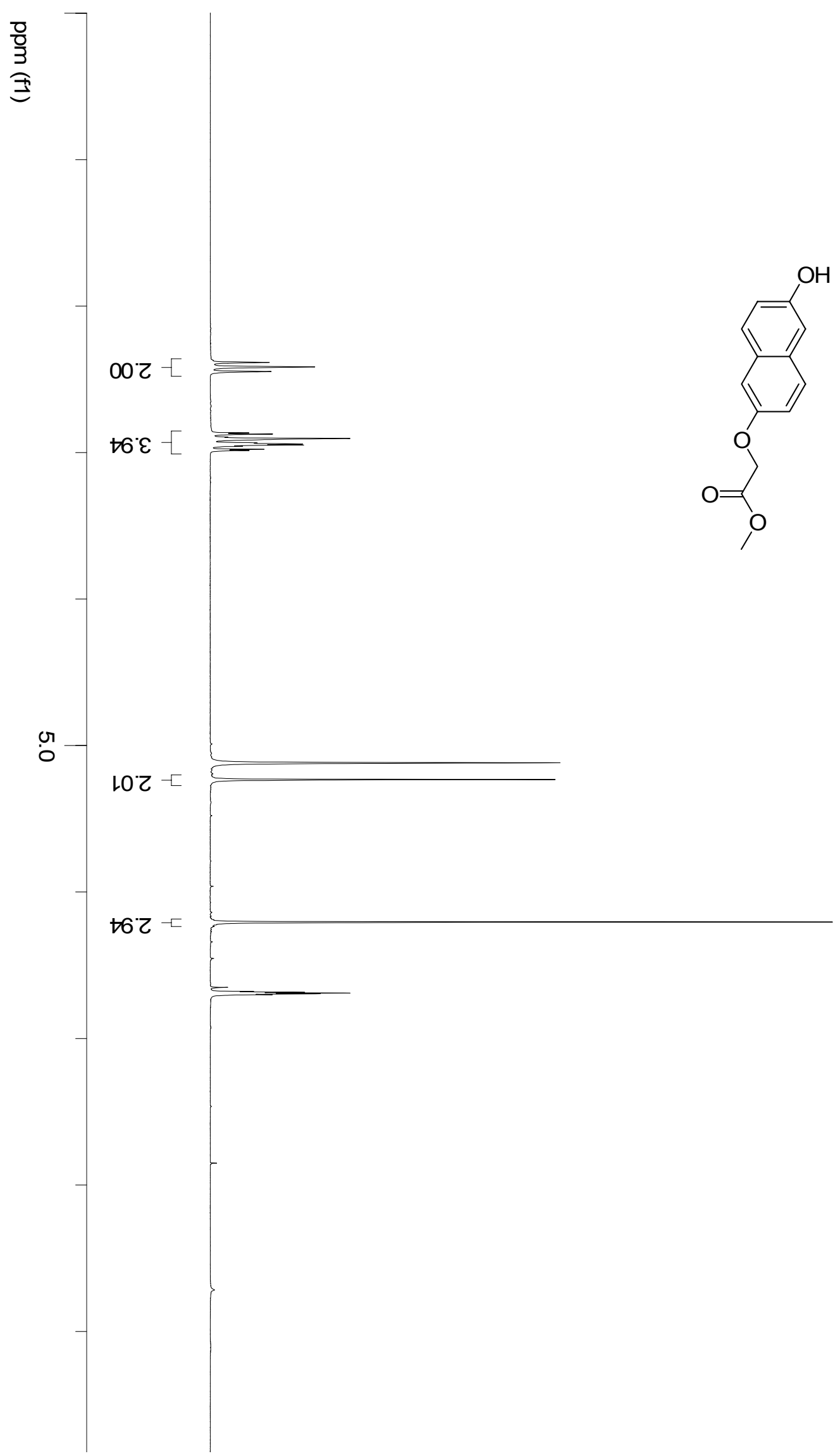




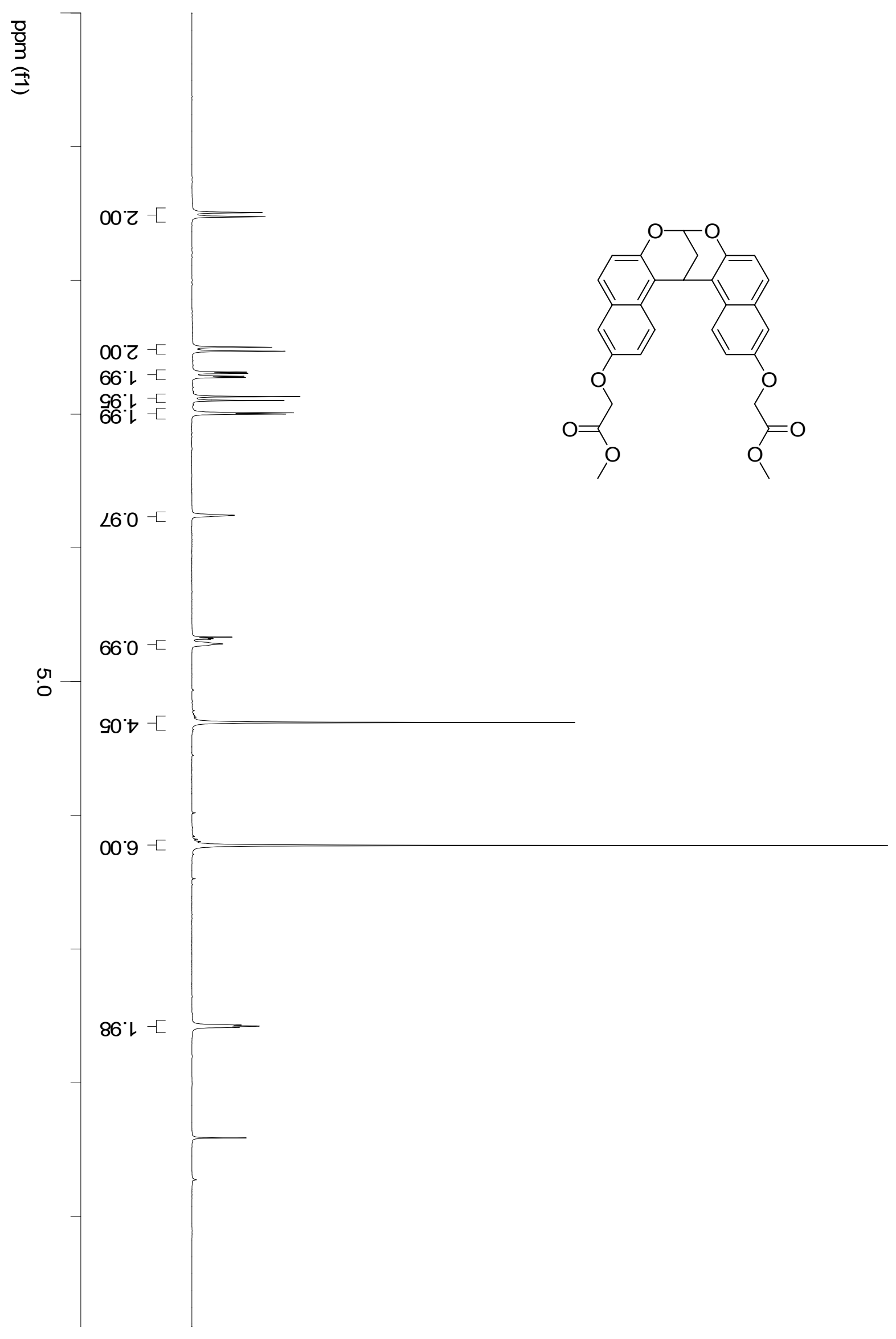




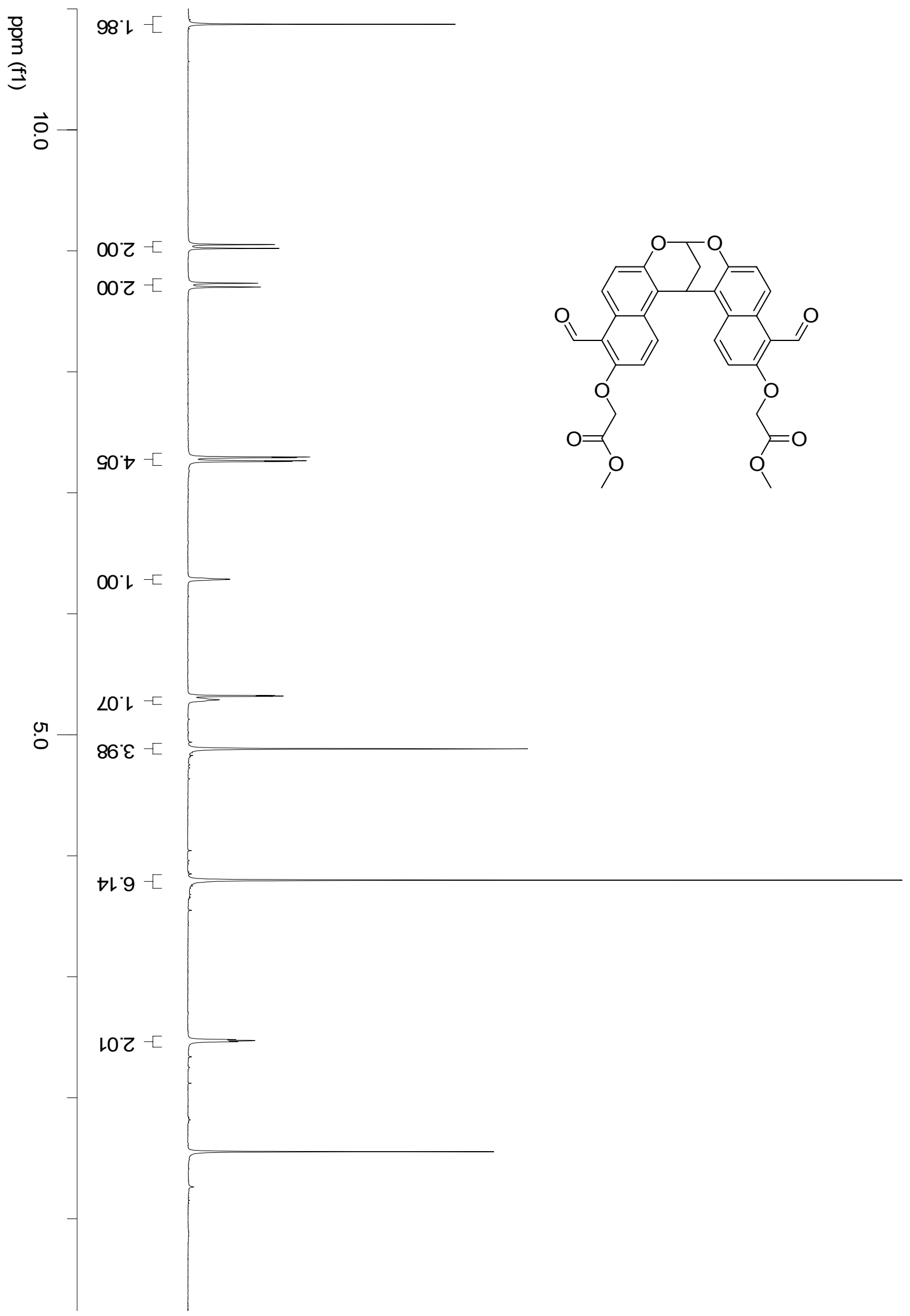




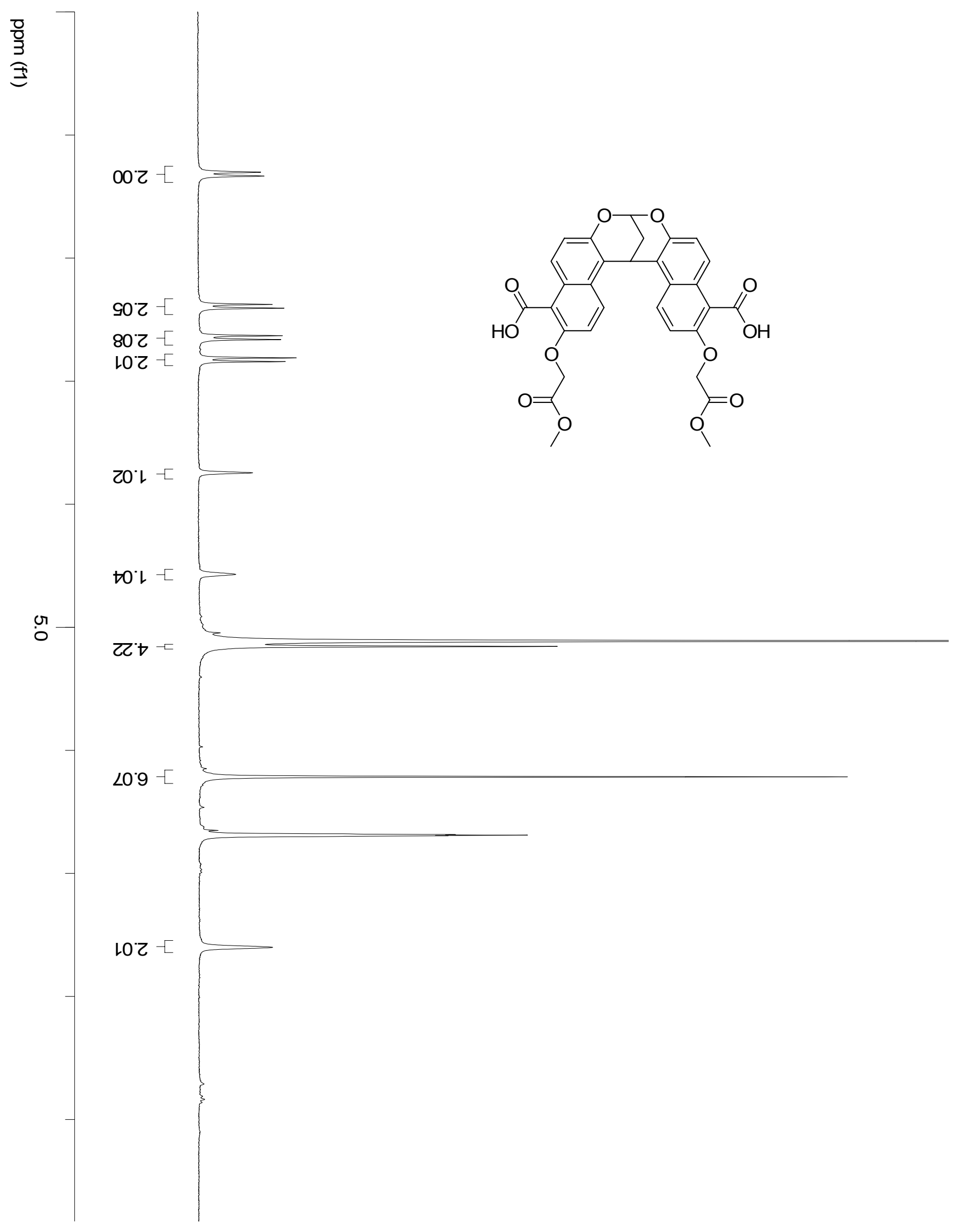




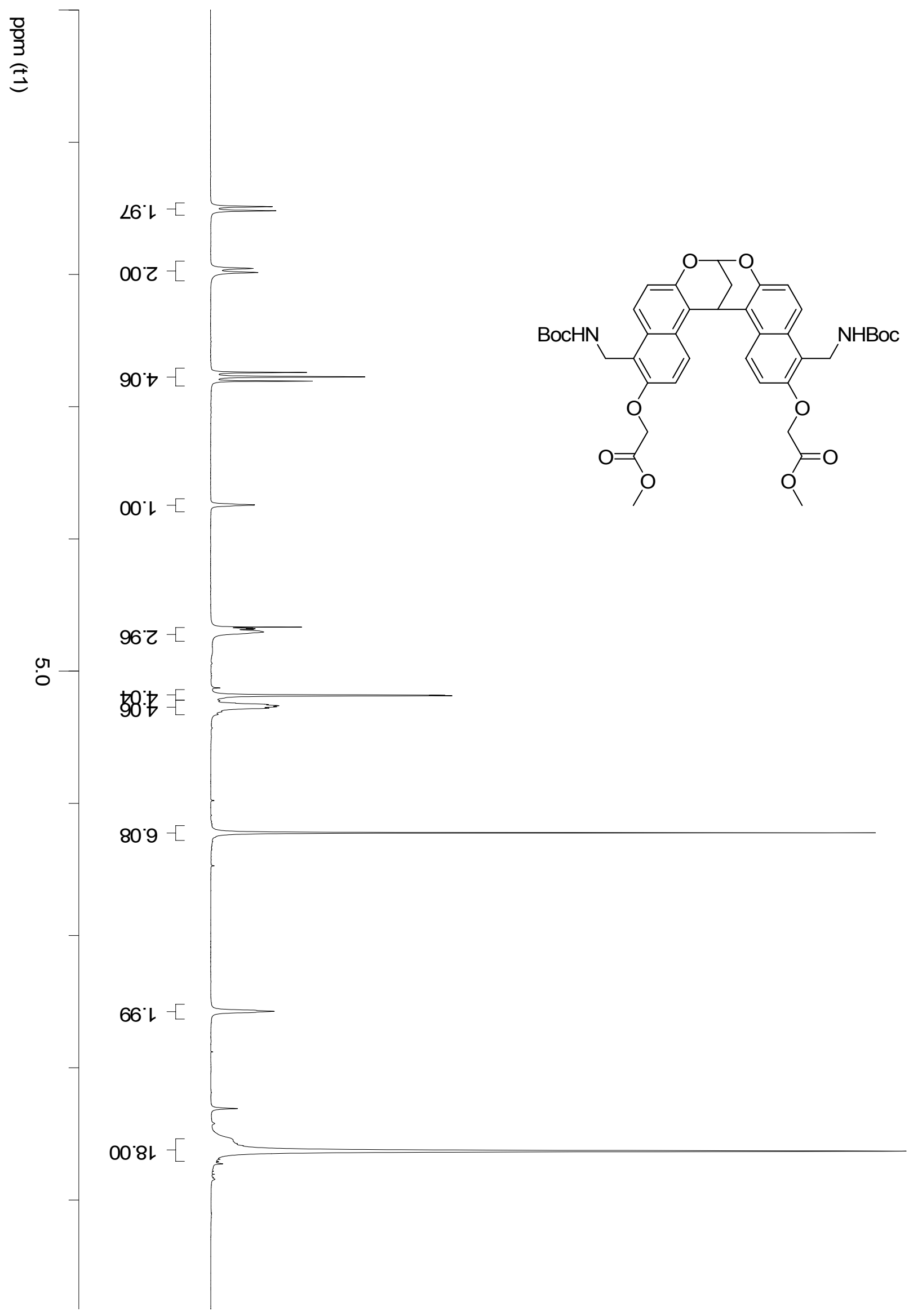



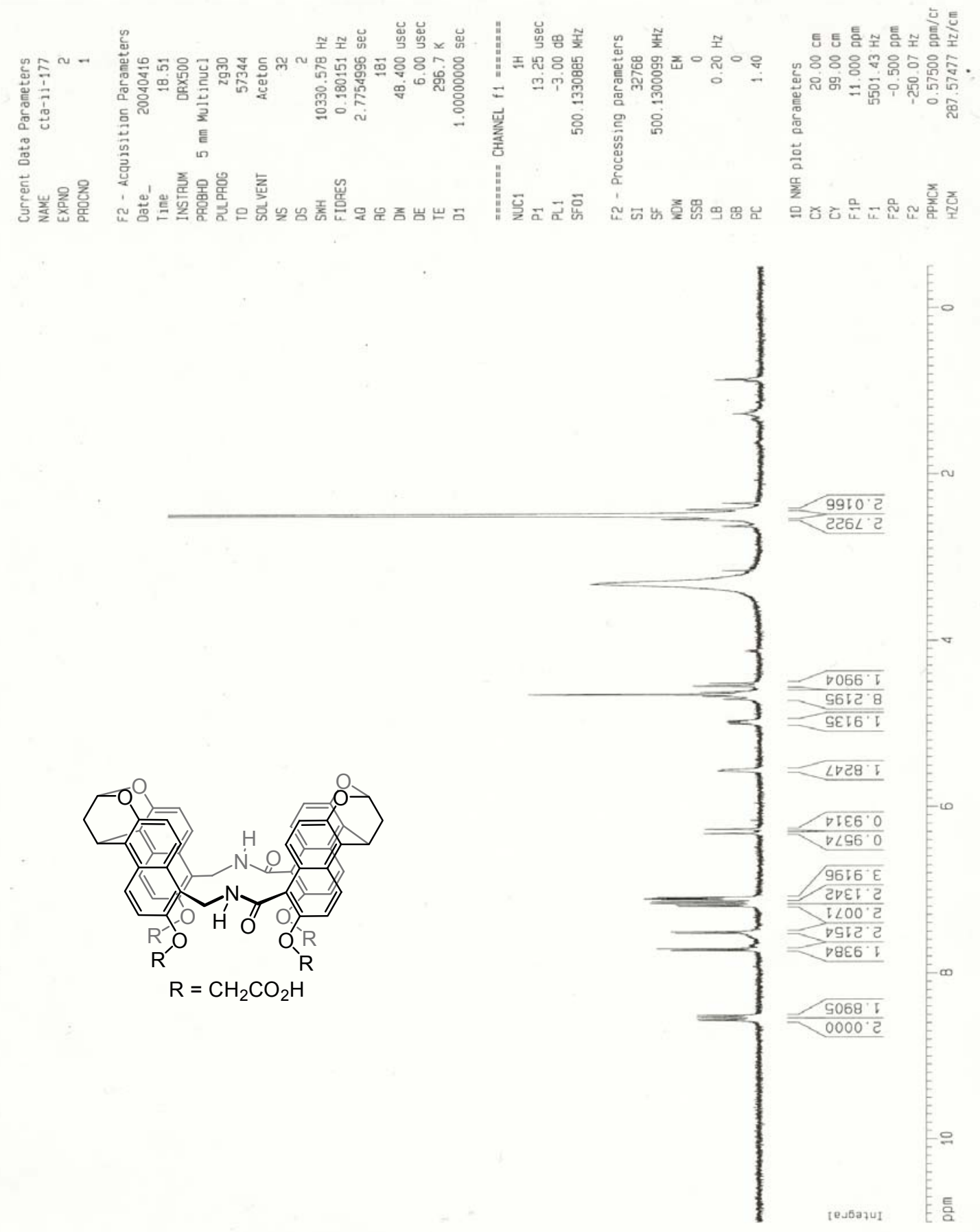

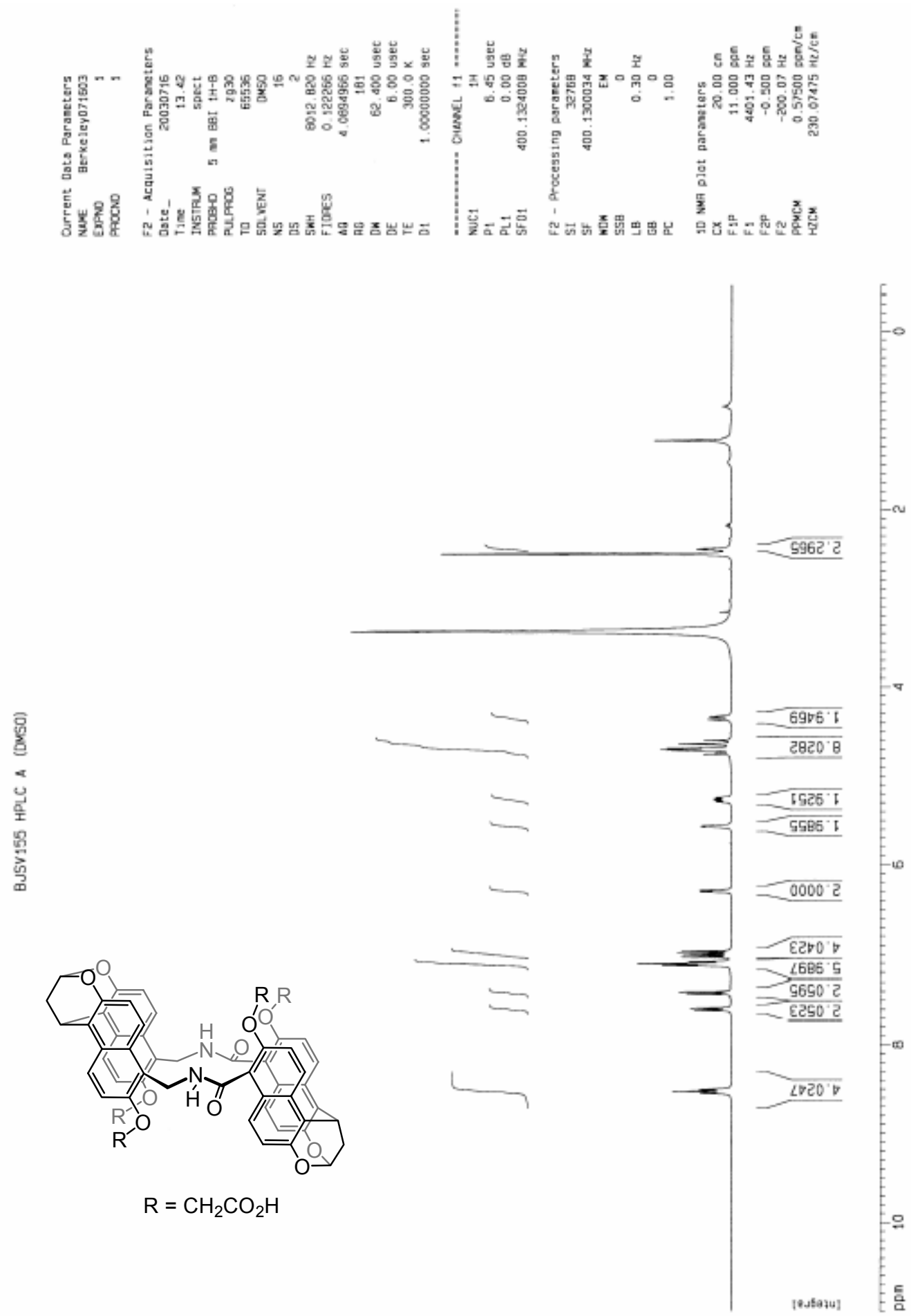